\title{
ALIH KODE DAN CAMPUR KODE \\ DALAM TUTURAN BAHASA INDONESIA OLEH MAHASISWA FAKULTAS PERTANIAN UNIVERSITAS WINAYA MUKTI
}

\author{
Lilis Amaliah Rosdiana ${ }^{1}$, Dadang Sunendar ${ }^{2}$, Vismaia S. Damaianti ${ }^{3}$ \\ ${ }^{1}$ Universitas Winaya Mukti \\ ${ }^{123}$ Universitas Pendidikan Indonesia \\ lilisamaliah87@gmail.com
}

\begin{abstract}
The purpose of this study is to find out the code transfer picture and mix sundanese sound codes in Indonesian conversation. The method used is qualitative descriptive method. The source of this research data is students of The Agricultural Faculty of Winaya Mukti University. Data collection is done with capable simak techniques, free-to-read techniques, recording techniques, and documentation techniques. The results obtained from this study are as follows: (1) The code transfer in student speech can be grouped into two types, namely internal code transfer and external code transfer. Internal code switching tends to take the form of: (a) switching the code from Indonesian to sundanese language; and (b) transfer the internal code from Sundanese to Indonesian. Then the transfer of external code that occurs in students with the tendency to change the code from English to Indonesian. (2) While the mix of codes that occur in the speech of students tends to be shaped only mix code out (Outer Code Mixing) that is tend to be in the form of mixed Indonesian-Sundanese-English language in one sentence.
\end{abstract}

Key words: code transfer, mix code, Indonesian speech

\begin{abstract}
ABSTRAK
Tujuan penelitian ini adalah untuk mengetahui gambaran alih kode dan campur kode bunyi bahasa Sunda dalam percakapan bahasa Indonesia. Metode yang digunakan adalah metode deskriptif kualitatif. Sumber data penelitian ini adalah mahasiswa Fakutas Pertanian Universitas Winaya Mukti. Pengumpulan data dilakukan dengan teknik simak cakap, teknik simak bebas libat cakap, teknik rekam, dan teknik dokumentasi. Hasil yang didapat dari penelitian ini adalah sebagai berikut: (1) Alih kode dalam tuturan mahasiswa dapat dikelompokan ke dalam dua jenis yaitu alih kode intern dan alih kode ekstern. Alih kode intern berkecenderungan berbentuk: (a) alih kode dari bahasa Indonesia ke dalam bahasa Sunda halus; dan (b) alih kode intern dari bahasa Sunda ke dalam bahasa Indonesia. Kemudian alih kode ekstern yang terjadi pada mahasiswa berkecenderungan berbentuk alih kode dari bahasa Inggris ke dalam bahasa Indonesia. (2) Sedangkan campur kode yang terjadi dalam tuturan mahasiswa berkecenderungan berbentuk hanya campur kode ke luar (Outer Code Mixing) yaitu berkecenderungan berbentuk campur bahasa Indonesia-Sunda-Inggris di dalam satu kalimat.
\end{abstract}

Kata Kunci: alih kode, campur kode, tuturan bahasa Indonesia

How to Cite: Lilis Amaliah Rosdiana, Sunendar, D., \& Damaianti, V. S. (2021). ALIH KODE DAN CAMPUR KODE DALAM TUTURAN BAHASA INDONESIA OLEH MAHASISWA FAKULTAS PERTANIAN UNIVERSITAS WINAYA MUKTI. Bahtera Indonesia; Jurnal Penelitian Bahasa Dan Sastra Indonesia , 6(2), 178-188. https://doi.org/10.31943/bi.v6i2.120 
DOI: $\underline{\text { https://doi.org/10.31943/bi.v6i2.120 }}$

\section{PENDAHULUAN}

Bahasa adalah ciri manusiawi yang dipakai oleh manusia yang menjadi pembeda antara manusia dengan ciptaan lainnya. Bahasa yang dipakai sebagai alat komunikasi merupakan suatu bagian yang paling penting dari kebudayaan yang juga menggambarkan semua aspek kebudayaan. Devianty (2017) mengatakan, banyak fungsi bahasa terhadap kebudayaan, seperti sebagai sarana pengembangan kebudayaan, sarana pembinaan kebudayaan, jalur pembinaan kebudayaan, dan sarana inventarisasi kebudayaan.

Oleh karena itu, bahasa tidak dapat dipisahkan dari kehidupan budaya manusia karena antara bahasa dan budaya memiliki hubungan kausalitas atau hubungan timbalbalik. Bahasa merupakan salah satu hasil budaya manusia, sedangkan budaya manusia banyak pula dipengaruhi oleh bahasa. Lebih penting dari itu, kebudayaan manusia tidak akan dapat terjadi tanpa bahasa karena bahasalah faktor yang memungkinkan terbentuknya kebudayaan. Jadi, bahasa merupakan cerminan kebudayaan suatu masyarakat.

Barus (2019) mengatakan dalam kehidupan sehari-hari manusia selalu berhubungan dengan yang lain, setiap individu mempunyai perannya masingmasing bergerak dan memengaruhi lingkungan di sekitarnya, begitu juga sebaliknya alam sekitar juga memengaruhi individu, baik tingkah laku, perbuatan, pikiran, sikap, perasaan, kemauan, dan lain sebagainya.

Adnyani (2013) dalam berkomunikasi akan ada peluang masuknya unsur suatu bahasa terhadap bahasa yang lain. Di dalam sebuah percakapan dapat terjadi masukya unsur bahasa daerah terhadap bahasa Indonesia atau sebaliknya, dan hal itu dapat terjadi pada seluruh masyarakat dwibahasa, baik masyarakat pada umumnya maupun masyarakat pelajar di lingkungan sekolah.

Penggunaan bahasa Indonesia di kalangan remaja perlu sekali untuk dipertahankan karena mahasiswa inilah yang akan menjadi ujung tombak pemertahanan bahasa Indonesia itu sendiri. Membudayakan bahasa daerah tentu juga bukan sekadar kewajiban lagi. Namun harus menjadi kebiasaan masyarakat setempat. Sehingga kesadaran berbahasa harus dimiliki seluruh warga negara Indonesia. Bahasa daerah yang dipilih dalam penelitian ini adalah bahasa Sunda. Bahasa Sunda merupakan alat komunikasi utama dalam masyarakat Sunda.

Dalam kegiatan rumah tangga, antartetangga, maupun antaranggota 
masyarakat, bahasa Sunda dipakai sebagai media. Pada umumnya bahasa Sunda digunakan sebagai bahasa pengantar proses belajar mengajar di sekolah dasar pada kelas satu dan kelas dua. Namun, yang menjadi masalah saat ini bahwa penutur bahasa Sunda dalam berbahasa Indonesia melakukan campur kode dan alih kode bunyi bahasa Sunda.

Faktor-faktor yang membuat terjadinya alih kode seperti hubungan antarpembicara dan pendengar, variasi bahasa, tujuan berbicara, topik yang dibahas, waktu tempat berbincang. Alih ragam hanya terjadi dalam satu bahasa dan satu komunitas saja. Hymes dalam Chaer (2010) mengatakan "Alih kode itu bukan hanya terjadi antarbahasa, tetapi dapat juga terjadi antara ragam-ragam atau gaya-gaya yang terdapat dalam satu bahasa"

Werdiningsih (2016) mengungkapkan bahwa sikap berbahasa dari seorang pemakai bahasa atau masyarakat bahasa baik yang dwibahasawan maupun multibahasawan akan berwujud berupa perasaan bangga atau mengejek, menolak sekaligus menerima suatu bahasa tertentu atau masyarakat pemakai bahasa tertentu, baik terhadap bahasa yang dikuasai oleh setiap individu maupun oleh anggota masyarakat.

Mahasiswa merupakan penutur yang memiliki intensitas yang tinggi dalam penggunaan ragam bahasa. Akibatnya interaksi antara mahasiswa atau mahasiswi sangat dinamis. Dinamika interaksi tersebut pun tercermin dalam hal pemilihan dan penggunaan bahasa yang tidak hanya satu bahasa atau ragam. Akibat lebih jauh digunakannya lebih dari satu bahasa atau ragam adalah munculnya fenomena alih kode dan campur kode dalam tuturan mahasiswa.

Peristiwa alih kode dan campur kode dapat terjadi dalam komunikasi lisan maupun tulisan. Dilihat dari sudut arah, alih kode dapat berupa bahasa Indonesia ke bahasa Jawa atau sebaliknya, alih kode dari bahasa Indonesia ke bahasa Sunda kasar, alih kode dari bahasa Sunda kasar ke bahasa Indonesia, alih kode dari bahasa Sunda ke dalam bahasa Jawa. Campur kode dari sudut bentuk dapat berupa klausa atau kalimat, frasa atau kata, campur kode bahasa Jawa dalam bahasa Indonesia, campur kode bahasa Jawa dalam bahasa Sunda kasar, campur kode bahasa Indonesia ke bahasa Sunda kasar. Gejala alih kode dari segi bentuk dapat terjadi alih bahasa atau ke alih ragam, bisa juga terjadi dari alih ragam ke alih bahasa. Pemilihan ini sebagai objek penelitian didasarkan atas asumsi bahwa dalam tuturan mahasiswa Fakultas Pertanian Unwim tersebut terdapat percampuran bahasa, yaitu bahasa Indonesia dan bahasa Sunda. Mahasiswa Fakultas Pertanian Unwim mayoritas berasal dari daerah Sunda. Itulah sebabnya bahasa Sunda masih terjaga dengan baik. Begitupun 
penggunaan Bahasa Indonesia, tetapi ada kalanya mereka menggabungkan bahasa Sunda tersebut dengan bahasa Indonesia dalam satu percakapan. Mereka menjadi telah terbiasa dengan hal tersebut.

Berkaitan dengan masalah itu, dipandang perlu diadakan penelitian alih kode dan campur kode bunyi bahasa Sunda dalam percakapan bahasa Indonesia. Tujuan dilakukannya penelitian ini adalah untuk mengetahui gambaran alih kode dan campur kode bunyi bahasa Sunda dalam percakapan bahasa Indonesia di kalangan mahasiswa Fakultas Pertanian Unwim.

\section{METODE PENELITIAN}

Penelitian ini menggunakan metode deksriptif kualitatif. Sujana dalam Agustinuraida (2017) mengemukakan bahwa masalah penelitian yang tepat dikaji melalui metode deskripsi biasanya berkenaan dengan kondisi, proses, karakteristik, hail dari suatu variabel. Data penelitian dikumpulkan melalui hasil rekaman tuturan mahasiswa Fakultas Pertanian saat berkomunikasi di kelas dan di luar kelas. Untuk pelaksanaan penelitian ini penulis menggunakan teknik pengumpulan data sebagai berikut.

1) Teknik Studi Pustaka.

Teknik ini dilakukan untuk melengkapi pemahaman dan pengetahuan dalam memecahkan masalah yang dihadapi.
2) Observasi.

Observasi dilakukan untuk memperoleh informasi langsung ke lapangan yang akan dilakukan peneliti kepada objek yang akan di teliti. Sasarannya adalah mahasiswa Fakultas Pertanian Unwim. Observasi dalam penelitian ini menggunakan beberapa teknik, yaitu:

a. Teknik Simak Libat Cakap

Kegiatan dalam teknik simak libat sikap cakap yang dilakukan pertama-tama adalah berpartisipasi dalam pembicaraan dan menyimak pembicaraan, jadi peneliti terlibat langsung dalam dialog (Sudaryanto, 2015).

b. Teknik Simak Bebas Libat Cakap

Tenik simak bebas libat cakap artinya peneliti tidak ikut terlibat dalam dialog, konversasi, atau tibal wicara, jadi tidak ikut serta dalam proses pembicaraan orang-orang yang saling berbicara. Peneliti hanya sebagai pemerhati yang dengan penuh minat tekun mendengarkan apa yang apa yang dikatakan (dan bukan apa yang dibicarakan) oleh orang-orang yang hanyut dalam proses dialog (Sudaryanto, 2015). 
c. Teknik Rekam

Teknik rekam tidak perlu ditegaskan ulang karena pelaksanaan merekam itu sudah tentu harus dilakukan sedemikian sehingga tidak mengganggu kewajaran proses kegiatan pertuturan yang sedang terjadi sehingga dalam prakteknya, kegiatan merekam itu atau setidak-tidaknya tujuan khusus yang sebenarnya tindakan merekam itu cenderung selalu dilakukan tanpa sepengetahuan penutur sumber data atau pembicara atau orang yang bicara (Sudaryanto, 2015).

\section{d. Teknik Dokumentasi}

Teknik ini digunakan dalam rangka memperoleh data tertulis mengenai proses komunikasi. Dokumentasi asal katanya dokumen yang artinya barang-barang tertulis. (Arikunto, 2013).

Data yang telah terkumpul selanjutnya diolah menggunakan teknik deskriptif dari hasil penelitian alih kode dan campur kode. Untuk membuahkan hasil yang objektif, di perlukan teknik pengolahan data. Langkahlangkah yang harus ditempuh sebagai berikut.

1) Melakukan putaran ulang hasil penelitian dalam alat rekam.
2) Memindahkan hasil penelitian dari rekaman ke dalam tulisan secara utuh.

3) Menganalisis dengan menandai bahasa yang termasuk alih kode dan campur kode.

4) Membahas penelitian tersebut berdasarkan teori yang sudah ditentukan.

5) Menyebutkan hasil penelitian yang berupa simpulan.

\section{HASIL DAN PEMBAHASAN}

Bahasa berperan sebagai sarana komunikasi. Pada dasarnya kegiatan interaksi dan komunikasi tidak akan berjalan dengan baik dan benar tanpa adanya bahasa sebagai alat yang digunakan dalam melakukan dua kegiatan tersebut. Menurut Kridalaksana (2008) bahasa adalah sistem lambang bunyi yang bersifat arbitrer yang digunakan oleh suatu masyarakat untuk bekerja sama, berinteraksi, dan mengidentifikasikan diri. Sistem lambang bunyi ini sangat berguna karena tanpanya, seseorang tidak akan mampu mengekspresikan diri dan kemauannya kepada orang lain.

Sikap bahasa merupakan sikap seseorang terhadap penutur atau dialek. Sikap bahasa memungkinkan segala macam perilaku tentang bagaimana bahasa diperlakukan, termasuk sikap terhadap pemertahanan bahasa dan upaya-upaya perencanaan bahasa. Sikap terbentuk dari interaksi sosial yang dialami seseorang yang 
dalam berinteraksi individu akan membentuk pola tertentu terhadap objek yang dihadapinya (Sugiyono dalam Astuti, 2017).

Bahasa yang digunakan oleh masyarakat Indonesia adalah bahasa Indonesia dan bahasa daerah atau yang disebut dengan bahasa Ibu. Kedua bahasa ini mempunyai kedudukannya masing-masing dan terkadang keduanya digunakan dalam satu situasi yang sama. Pertama bahasa ibunya sendiri atau bahasa pertamanya, dan yang kedua adalah bahasa lain yang menjadi bahasa keduanya. Orang yang dapat menggunakan kedua bahasa.

Faktor masyarakat bilingual atau bahkan multilingual bisa disebabkan oleh beberapa sebab, misalnya faktor migrasi yaitu perpindahan penduduk yang menyebabkan keanekabahasaan. Kelompok kecil yang berimigrasi ke daerah atau negara lain tentu menyebabkan bahasa ibu mereka tidak berfungsi di daerah baru, selain itu faktor pendidikan sangat memengaruhi. Biasanya sekolah mengajarkan bahasa asing kepada anak-anak yang menyebabkan si anak menjadi bilingual atau bahkan multilingual. Berkaitan dengan bahasa sebagai alat komunikasi, seseorang di samping perlu berkomunikasi dengan anggota masyarakat bahasa sekitarnya, mereka juga perlu berkomunikasi dengan anggota masyarakat bahasa lain dan daerah lain, guna memenuhi kelancaran dalam bersosialisasi. Di antara sesama penutur yang bilingual atau multilingual, sering dijumpai suatu gejala yang dapat dipandang sebagai suatu kekacauan atau interferensi berbahasa (Performance Interference).

Suatu keadaan berbahasa ialah bilamana orang mencampur dua (atau lebih) bahasa atau ragam bahasa dalam suatu tindak bahasa (speech act atau discourse) tanpa ada sesuatu dalam situasi berbahasa itu yang menuntut pencampuran bahasa itu. Pada saat mengadakan interaksi, di antara pemakai bahasa yang satu dengan yang lain akan timbul kontak bahasa yang satu dengan yang lain akan timbul suatu kontak bahasa. Dalam keadaan demikian, hanya kesantaian penutur dan/atau kebiasaannya yang dituruti. Tindak bahasa yang demikian kita sebut campur kode. Di Indonesia campur kode ini sering sekali terdapat dalam keadaan orang berbincang-bincang. Begitu juga yang dialami oleh mahasiswa Fakultas Pertanian Unwim yang dicampur ialah bahasa Indonesia dan bahasa daerah (Sunda).

Campur kode dan alih kode tidak bisa terlepas dalam penggunaan bahasa Indonesia dan bahasa daerah atau dialek. Mahasiswa dan dosen secara sadar atau tidak sadar kerap melakukan alih kode dan campur kode. Alih kode (code switching) adalah penggunaan variasi bahasa lain atau bahasa lain dalam satu peristiwa bahasa sebagai strategi untuk menyesuaikan diri dengan peran atau situasi 
lain, atau karena adanya partisipan lain (Kridalaksana: 2008). Kemudian Saddhono (2014) mengatakan bahwa alih kode berdasarkan sifatnya dapat dibagi menjadi dua, yaitu alih kode internal dan alih kode eksternal. Alih kode internal terjadi apabila ada penyisipan bahasa daerah ke bahasa Indonesia sedangkan alih kode eksternal terjadi apabila terjadi peralihan antara bahasa asli ke bahasa asing (Simatupang dalam Agustinuraida, 2018). Alih kode memiliki fungsi untuk (a) menjelaskan, menanyakan, (c) menegur, (d) menegaskan, dan (e) mengingatkan.

\section{Alih Kode}

Appel (dalam Chaer 2010) mendefinisikan alih kode sebagai "gejala peralihan pemakaian bahasa karena berubahnya situasi”. Kridalaksana (2008) setuju dengan pendapat ini dan menambahkan bahwa alih kode adalah penggunaan variasi bahasa lain untuk menyesuaikan diri dengan peran atau situasi lain, atau karena adanya partisipasi lain. Seperti dinyatakan oleh Hymes dalam Agustinuraida (2017) alih kode dapat terjadi tidak hanya antarbahasa, namun juga dapat dilakukan antar ragam-ragam atau gaya-gaya yang terdapat dalam suatu bahasa, atau bahkan dalam gaya yang terdapat pada sauatu bahasa.

Berdasarkan beberapa definisi tersebut, dapat disimpulkan bahwa alih kode adalah terjadinya peralihan antarbahasa atau ragam dan gaya bahasa dalam satu ujaran atau percakapan yang disebabkan karena berubahnya situasi atau partisipasi lain.

\section{Campur Kode}

Menurut Nababan dalam

Agustinuraida (2017) campur bahasa merupakan mencampur dua atau lebih bahasa atau ragam bahasa dalam suatu tindakan bahasa (speech act atau discourse) tanpa ada sesuatu dalam situasi berbahasa itu yang menuntut pencampuran bahasa itu. Dalam keadaan yang demikian, hanya kesantaian penutur dan atau kebiasaannya yang dituruti.

Berdasarkan pernyataan tersebut dapat dinyatakan bahwa pencampuran bahasa tidak dipengaruhi oleh situasi berbahasa. Berdasarkan konsep Nababan mengenai campur kode, situasi tutur tidak berperan penting dalam mempengaruhi campur tutur. Justru kesantaian dan kebiasaanlah yang menentukan atau mempengaruhi seseorang dalam melakukan campur kode

Berikut ini peneliti sajikan beberapa data alih kode dan campur kode bahasa Sunda terhadap bahasa Indonesia yang dilakukan mahasiswa Fakultas Pertanian Unwim.

\section{Alih Kode Intern}

a. Alih Kode Intern (Bahasa Indonesia ke Bahasa Sunda Ragam Halus)

A: "Mau ada acara apa ini?" 
B: "Eh Ibu, bade aya buka bersama. Ibu hadir nya ke sonten"

A: "Aduh, ibu mah kumaha atuh da teu tiasa uih sonten. Prokesna we kade kedah dijagi."

$\mathrm{C}$ : "Pasti $\mathrm{Bu}$, supados sarehat sadayana."

Tujuan percakapan di atas menunjukan alih kode intern yaitu alih kode yang berlangsung antar bahasa sendiri berupa alih kode dari bahasa Indonesia ke dalam bahasa Sunda ragam halus. Seorang dosen bertanya kepada mahasiswa yang ia temui menggunakan bahasa Indonesia ragam santai seperti ditunjukan dalam kalimat 'Mau ada acara apa ini?', dan ditanggapi oleh mahasiswa ke-1 dengan menggunakan bahasa Sunda 'Eh Ibu, bade aya buka bersama. Ibu hadir nya ke sonten' (Eh Ibu, mau ada buka puasa- bersama. Ibu hadir ya nanti sore). Percakapan antara dosen dan mahasiswa pun akhirnya beralih bahasa menggunakan bahasa Sunda karena mahasiswa tersebut menjawab menggunakan bahsa Sunda ragam halus. Hal ini menunjukan adanya perpindahan bahasa dari bahasa Indonesia ragam santai ke dalam bahasa Sunda ragam halus. Berdasarkan hal tersebut, lawan bicara dapat menyebabkan terjadinya alih kode karena penutur menyesuaikan dan mengimbagi bahasa yang digunakan oleh lawan bicaranya.

\section{b. Alih Kode Intern dari bahasa Sunda ke bahasa Indonesia}

A: "Rek ka kosan abi heula moal?'
B. "Enggak, mau langsung pulang aja. Mau beres-beres."

A: "Naha beberes? Rek uih?"

B: "Iya mau mudik dari sekarang takut dicegat"

A: "Mau mudik ke Cianjur, Nit?"

B: "Ya"

Tujuan percakapan di atas menunjukan alih kode intern yaitu alih kode yang berlangsung antar bahasa sendiri berupa alih kode dari bahasa Sunda ke Bahasa Indonesia. Pertama kali mahasiswa A bertanya kepada mahasiswa B menggunakan bahasa Sunda seperti ditunjukan dalam kalimat 'Rek ka kosan abi heula moal?', dan ditanggapi oleh mahasiswa B dengan menggunakan bahasa Indonesia. 'Enggak, mau langsung pulang aja. Mau beres-beres'. Mahasiswa A pada akhirnya beralih bahasa menggunakan bahasa Indonesia karena temannya menggunakan bahasa Indonesia, seperti ditunjukan dalam kalimat 'Mau mudik ke Cianjur?'. Hal ini menunjukan adanya perpindahan bahasa dari bahasa Sunda ke dalam bahasa Indonesia.

\section{Alih Kode Ekstern}

Alih kode ekstern adalah alih kode yang berlangsung antar bahasa sendiri (salah satu bahasa atau ragam yang ada dalam verbal reportoir masyarakat tuturnya) dengan bahasa asing. Seperti dari bahasa Indonesia ke bahasa Inggris, alih kode bahasa Inggris ke bahasa Indonesia. 
a. Alih Kode dari Bahasa Inggris ke dalam Bahasa Indonesia

A: "Wait the minute, I'll be back"

B: "Mau ke mana?"

A: "Kantin. Mau beli minum. Mau nitip apa?"

B: "Titip teh kotak 1"

A: "Siap"

Tuturan percakapan di atas menunjukan alih kode yang berlangsung antar bahasa sendiri (salah satu bahasa bahasa atau ragam yang ada dalam verbal reportoir masyarakat tuturnya) dengan bahasa asing.

Alih kode tersebut berupa alih kode dari bahasa Inggris ke dalam bahasa Indonesia. Mahasiswa A menggunakan bahasa Inggris seperti ditunjukan dalam kalimat 'Wait the minute. I'll be back' dan ditanggapi oleh mahasiswa $\mathrm{B}$ dengan menggunakan bahasa Indonesia, 'Mau ke mana?'. Kemudian mahasiswa A beralih menggunakan bahasa Indonesia, 'Kantin. Mau beli minum. Mau nitip apa?'. Hal ini menunjukan adanya perpindahan bahasa dari bahasa Inggris ke dalam bahasa Indonesia. Penutur ingin menyesuaikan bahasa yang digunakan oleh lawan tuturnya agar percakapan berjalan lancar.

\section{Campur Kode Keluar (Outer Code} Mixing)

Wujud variasi piihan bahasa berupa campur kode bahasa yang terjadi pada peristiwa tutur mahasiswa Fakultas Pertanian
Unwim dapat berwujud campur kode keluar (Outher Code Mixing). Campur kode keluar maksudnya campur kode yang berasal dari bahasa asing dan sering terdapat dalam orang berbincang yang dicampur adalah bahasa Indonesia , bahasa daerah, dan bahasa asing. Seperti yang terjadi pada mahasiswa Fakultas Pertanian Unwim yang mencampurkan bahasa Indoesia-Sunda-Inggris.

A: "Jadi ga buka bersama ke Jatos?."

B: "Ih puguh aku lagi nunggu kabar, waiting list mau tetep di tempat itu mah.

A: "Gimana kalo pindah tempat atuh yu?"

Tuturan percakapan di atas menunjukan campur kode keluar yang dicampur adalah bahasa Indonesia, bahasa daerah, dan bahasa asing. Hal ini terkait pada percakapan mahasiswa B yang mencampur bahasa Indonesia, bahasa Sunda, dan bahasa asing dalam satu kalimat, 'Ih puguh aku lagi nunggu kabar, waiting list mau tetep di tempat itu mah.' Kemudian ditanggapi oleh mahasiswa A yang juga mencampur bahasa Indonesia dengan bahasa sunda, 'Gimana kalo pindah aja atuh yu?'. Dari percakapan tersebut menunjukan adanya penampuran bahasa dari bahasa Indonesia, Sunda, dan Inggris dalam percakapannya tetapi hal tersebut tidak mengganggu pemahaman makna yang terjadi pada kedua mahasiswa tersebut.

Dari ketiga gejala bahasa di atas, dalam tuturan mahasiswa Fakultas Pertanian 
memang terjadi alih kode dan campur kode yang pada kesehariannya sulit umtuk dihindari. Alih kode dan campur kode tersebut rata-rata tujuannya supaya menambah kesan keakraban di antara penuturnya. Walaupun demikian, kedua penutur dalam setiap percakapan tetap bisa memahami apa yang dibicarakan lawan tuturnya. Kejadian alih kode dan campur kode tetap tidak mengganggu makna dari maksud setiap percakapan yang mereka lakukan.

\section{SIMPULAN}

Berdasarkan hasil pemaparan di atas, hasil penelitian terhadap alih kode dan campur kode dalam tuturan mahasiswa Fakultas Pertanian Unwim, didapat simpulan sebagai berikut:

1. Alih kode dalam tuturan mahasiswa dapat dikelompokan ke dalam dua jenis yaitu alih kode intern dan alih kode ekstern. Alih kode intern berkecenderungan berbentuk: (a) alih kode dari bahasa Indonesia ke dalam bahasa Sunda halus; dan (b) alih kode intern dari bahasa Sunda ke dalam bahasa Indonesia. Kemudian alih kode ekstern yang terjadi pada mahasiswa berkecenderungan berbentuk alih kode dari bahasa Inggris ke dalam bahasa Indonesia.

2. Sedangkan campur kode yang terjadi dalam tuturan mahasiswa berkecenderungan berbentuk hanya campur kode ke luar (Outer Code Mixing) yaitu berkecenderungan berbentuk campur bahasa Indonesia-Sunda-Inggris di dalam satu kalimat.

\section{DAFTAR PUSTAKA}

Adnyani, N.M, dkk. 2013. Campur Kode dalam Bahasa Indonesia Lisan Siswa Kelas VII SMPN 8 Denpasar. Jurnal Pendidikan dan Pembelajaran Bahasa Indonesia. 2 (2013) [Online] Tersedia pada https://ejournalpasca.undiksha.ac.id/index.php/jurnal bahasa/article/view/550 diunduh pada 1 April 2021.

Agustinuraida, I. 2017. Alih Kode dan Campur Kode dalam Tuturan Bahasa Indonesia Oleh Mahasiswa Prodi Pendidikan Bahasa Indonesia Universitas Galuh Ciamis. Jurnal Ilmiah Diksatrasia. 1(2) 65-75. [Online] Tersedia pada https://jurnal.unigal.ac.id/index.php/d iksatrasia/article/view/583 Diunduh pada 18 April 2021.

Arikuto, S. 2013. Prosedur Penelitian Suatu Pendekatan Praktik.

Astuti, A. Y. 2017. Penggunaan Bahasa Daerah pada Remaja di Wilayah Perbatasan Budaya Jawa dan Sunda (Studi Kasus di Desa Cipajang Kecamatan Banjarharjo Kabupaten Brebes. Universitas NegeriSemarang. Skripsi: Tidak diperjualbelikan.

Barus, J.I., Andoyo S., Isah C., 2019. Kajian Intervesi Bahasa Daerah Terhadap Bahasa Indonesia (Studi Campur Kode Bunyi Bahasa Karo dalam Percakapan Bahasa Indonesia). Prosiding Aeinar Internasional Riksa Bahasa. [Online] tersedia pada 
http://proceedings.upi.edu/index.php/ri ksabahasa diunduh pada 17 April 2021.

Chaer, Abdul dan Leonie Agustina. 2010. Sosiolinguistik Perkenalan Awal. Jakarta: Rineka Cipta.

Devianty, R. 2017. Bahasa Sebagai Cermin Kebudayaan. Jurnal Tarbiyah. 24(2) 226-245. [Online] Tersedia pada http://jurnaltarbiyah.uinsu.ac.id/index .php/tarbiyah/article/view/167 diunduh 17 April 2021.

Kridalaksana, H. 2008. Fungsi Bahasa dan Sikap Bahasa. Flores: Nusa Indah.

Mahsun. 2005. Metode Penelitian Bahasa. Jakarta: PT Raja Grafindo Cipta.

Saddhono, K., 2014. Kajian Sosiolinguistik Pemakaian Bahasa Mahasiswa Asing dalam Pembelajaran Bahasa Indonesia untuk Penutur Asing (BIPA) di Universitas Sebelas Maret. Kajian Linguisik dan Sastra, 24(2), 176-186. DOI:

https://doi.org/10.23917/kls.v24i2.96

Sudaryanto. 2015. Metode dan Aneka Teknik Analisis Bahasa (Pengantar Penelitian Wahana Kebudayaan Secara Linguistik). Yogyakarta: Duta Wacana University Pres.

Sugiyono. 2012. Metode Penelitian Kuantitatif, dan $R \& D$. Bandung: Alfabeta.

Werdiningsih, E. 2016. Menumbuhkan Rasa Bangga Gnerasi Muda Terhadap Bahasa Indonesia Sebagai Bahasa Nasional dan Internasional. LIKHITAPRAJNA: Jurnal
Ilmiah Fakultas Keguruan dan Ilmu Pendidikan. 18(2) 20-25. [Online] Tersedia pada http://likhitapradnya.wisnuwardhana.ac.i d/index.php/likhitapradnya/article/view/5 5 diunduh 10 April 2021. 